\title{
Gritty Cut Surface
}

National Cancer Institute

\section{Source}

National Cancer Institute. Gritty Cut Surface. NCI Thesaurus. Code C96185.

A descriptive term that is used in anatomic pathology and refers to the gritty appearance of the cut surface of a specimen. 